have had an order from Heaven on the subject; but that matters not-he is insane; the desire is the product of a diseased mind, and he is no more responsible for this disordered cerebration than is the epileptic who falls down convulsed in the street responsible for creating a disturbance and obstructing the thoroughfare.

The "opinion of the judges" still remains the letter of the law in England; but the spirit of the law, as displayed in the utterances of our most liberal-minded and enlightened judges, shows a considerable advance. It may truly be said that "the letter killeth, but the spirit giveth life."

I am, Sirs, yours faithfully,

March 5th, 1888 S. A. K. Strahan, M.D., Barrister-at-Law.

\section{"THE RADICAL CURE OF HYDROCELE BY EXCISION."}

To the Editors of THE LANCET.

Sirs,-From the report of the discussion which followed 'Mr. Henry Morris's paper on the Radical Cure of Itydrocele at the Medico-Chirurgical Society last week it would appear that the treatment by excision of the tunica vaginalis has not as yet become very generally adopted. Having now performed this operation in five cases, I should like to say a word or two in favour of it, for in my hands it has been attended by the most satisfactory results. Four of the cases have already been recorded in THE LANCET (September 10th, 1887), along with some remarks on the way in which the operation should be carried out. At the present time, three of the patients are still free from any evidence of recurrence of the bydrocele, and the fourth also was when last seen some months after the operation. The fifth case recently under my care was one of suppuration of a hydrocele after tapping, when the sac wall was in a very thickened condition. From a comparison of the results in these cases with those obtained in several others treated by injection and incision, 1 have come to the conclusion that in cases of hydrocele, especially when the tumour has been frequently tapped and the tunica vaginalis has become somewhat thickened, the excision method is by far the most certain means of bringing about a radical cure.-I am, Sirs, yours faithfully, F. A. SouTHAM, F.R.C S.

Asst.-Surgeon to the Manchester Royal Infirmary.

Manchester, March 6th, 1888.

\section{THE CHIAN TURPENTINE TREATMENT OF CANCER.}

\section{To the Editors of THE LANCET.}

Sirs,-In my letter on the above subject in THe LANCET of Dec. 17th I mentioned that $I$ had then under treatment by Chian turpentine a case of uterine cancer, and that in due course I would report the result. I regret to say that the issue has been a fatal one. The turpentine treatment was commenced at the period when the indurated cervix was beginning to break down, and was maintained up to a fortnight before death, when, owing to the great and continuous nausea produced, it was discontinued. Whilst the drug had no effect whatever in arresting the progress of the disease, the ulcerative process steadily progressing, and converting the cervix into an irregular, excavated chasm, it seemed to act beneficially in two respects. The discharge, never at any time great, was lessened; and the pain, which before taking the turpentine even increasingly large doses of opiates could not make bearable, was, with the exception of a short period before death, markedly diminished. I am, Sirs, yours truly,

Leytonstone, Feb. 27th, 1888. J. KrNG KenR, M.D.

\section{SMALL-POX ISOLATION NEAR BRISTOL.}

\section{To the Editors of The Lancet.}

Sirs,-In your last issue you make a statement on the authority of a member of the Bristol Sanitazy Authority that small-pox is extending and crossing the border into Bristol. This is misleading and contrary to the facts. In Stapleton sanitary district there are unfortunately two workhouses to which are attached small-pox hospitals. One of these workhouses is solely for Bristol; the other is for the use of 111,264 of the Bristol population, as well as for that of some neighbouring districts. Practically, then, Stapleton is the dumping ground for the sickness of Bristol. There was no small-pox in this district till it was brought from Bristol to one of the above workhouses, and thence it spread chiefly in the neighbourhood of the hospital, as is shown by a chart which I sent to the Local Government Board. In the same way the medical officer for St. George's thinks it arose in his district. Ilorfield, I understand, has only had two cases, and they were clearly traced to Bristol. As to the joint hospital, the matter fell through because the site selected was in the Stapleton district; and I think the objection was reasonable considering we have already two foci of infection. Our sanitary committee are taking the necessary steps to provide an infectious diseases hospital, It is now six weeks since the last case appeared in this district, and, with the exception of that case, all the others who were willing were properly isolated either in their own houses or in the hospital of the union, with the guardians of which we arranged for the reception of paying patients. $1 \mathrm{am}$, Sirs, yours truly,

$$
\text { Fishponds, March 5th, 1888. WILLIAM BROWN, }
$$

* * We can quite understand that the facts are as reported by Dr. Wm. Brown. For a long time past it has been evident that small-pox was being disseminated by reason of the objectionable practice of using workhouse buildings as small-pox hospitals. The difficulty of ascertaining the true facts has been due to the hospital being connected with a workhouse, and for that reason being subjected to no proper medical supervision by the central authority.-ED. L.

\section{LIVERPOOL. \\ (From our own Correspondent.)}

THE WINTER ASSIZRS.

Mr. Justice Grantham has been presiding in the Crown Court since the 18th ult. Among other prisoners brought before him was a Greek, a fireman on board an English vessel, charged with stabbing another Greek, who was also one of the crew. The latter would appear to have been a big, powerful fellow, and a great " bully," the prisoner, a small and comparatively weak man, being a frequent victim of his violence. On Jan. 31st, when within six days' sail of Liverpool, the deceased assaulted the prisoner with a backhanded stroke peculiar to Greek sailors. The prisoner, who was breakfasting at the time, stabbed the deceased on the buttock and front of the thigh, selecting these regions as being least dangerous. The deceased died from hæmorrhage seven hours afterwards, and was buried at sea. His clothes were produced, and cuts were visible on the front of the thigh and on that part which would cover the buttock. The knife was also produced, and had stains, apparently of blood, on the blade. The jury acquitted the prisoner. Another prisoner, a senman, was tried and sentenced to eighteen months' imprisonent with hard labour for stabbing the second mate in two places without any provocation.

\section{A UNIQUE CASE.}

Many cases of pregnancy after successful ovariotomy are on record, but such a fortunate sequence in a case where, before operation, the menopause had apparently been established for years, is not on record. The following is, however, such a case. The patient, a lady, gave birth to her last child in July, 1882, she being then thirty-five years of age. She did not nurse this child. Shortly after, menstruation became irregular, and finally ceased towards the end of 1884 , when she consulted Dr. Burton, surgeon to the Hospital for Women, who diagnosed a small ovarian tumour. No operation was then recommended, as the tumour was small and freely movable; so nothing was done beyond keeping the patient under observation until February, 1887, when the removal of the tumour was considered advisable. The operation was therefore performed by Dr. Burton ot the 18th of that month, when a small tumour, which subsequently proved to be a sarcoma of the right ovary, was removed. After this had been done the left ovary was examined. It was found to be small, ivory white, and indurated, and no suspicion existed in the minds of those who were present that it contained any more ova to mature. It was then returned. Exactly a month after the operation-viz, 